\title{
Introduction to Special Issue: New Directions in the Study of Advaita Vedānta
}

\author{
Michael S. Allen' ${ }^{1}$ Anand Venkatkrishnan ${ }^{2}$
}

Published online: 25 September 2017

(C) Springer Science+Business Media B.V. 2017

It seems hardly necessary to make a case for the historical significance of Advaita Vedānta, at least in modern times. From Orientalist scholars and Christian missionaries to nationalist reformers and New Age Gurus, Advaita Vedānta dominated a variety of discourses in nineteenth- and twentieth-century India. For some, it played the role of a universalist, nonsectarian philosophy that defined the spiritual core of a nascent nation. For others, it was an amoral, unworldly monism that reflected the prepolitical, unchanging character of a subject people. For still others, it represented a nondualist alternative to inherited modes of Western thought; at turns mystical and thoroughly rational, it could attract comparative philosophers and spiritual seekers alike.

Not only is Advaita Vedānta one of the most influential schools of Indian philosophy, it is also one of the most studied. Karl Potter's online Bibliography of Indian Philosophies lists more than nineteen hundred publications on Advaita Vedānta, far more than on any other school; over four hundred and fifty books and articles have appeared in the last twenty years alone. ${ }^{1}$ Whether or not its disproportionate impact on the field is justified, one might be forgiven for concluding that Advaita Vedānta has in fact been over-studied. Why devote further

\footnotetext{
1 And these figures refer only to general studies of Advaita Vedānta; they would be considerably higher were one to include editions, translations, and studies of specific texts and authors. Śankara studies, for example, is a field unto itself, with approximately eighteen hundred publications listed (see Potter 2017).
}

Michael S. Allen

msa2b@virginia.edu

Anand Venkatkrishnan

anand.venkatkrishnan@gmail.com

1 Department of Religious Studies, University of Virginia, Charlottesville, VA 22904, USA

2 Balliol College, University of Oxford, Oxford OX1 3BJ, UK 
attention to a tradition that has been "done" to death? Would it not be better to pursue less traveled paths?

To say that something has been studied much, however, is not necessarily to say it has been studied thoroughly and well. The articles in this issue make the cumulative argument that we do not yet understand the history of Advaita Vedānta nearly as well as one might think. To give a single, surprising example: scholars have yet to provide even a rudimentary, let alone comprehensive account of the history of Advaita Vedānta in the centuries leading up to the colonial period, though this history is precisely what set the stage for its modern reception. Scholarship on Advaita Vedānta has tended to focus overwhelmingly on Sankara, the founding figure of the tradition, but our knowledge of the thousand-year period between the Brahmasūtrabhāṣya and the lectures of Svāmī Vivekānanda remains largely incomplete.

The articles in this issue are devoted to new ways of approaching the study of Advaita Vedānta, with a focus on post-Śankkara Vedānta. They call into question received ideas about the tradition, they highlight neglected texts and figures, and perhaps most importantly, they suggest directions for future research. Several of the articles began as papers delivered at the 2013 Conference on South Asia at the University of Wisconsin-Madison, as part of a panel on "Advaita Vedānta on the Eve of Colonialism." This panel was inspired by the "Sanskrit Knowledge Systems on the Eve of Colonialism" project, which has made invaluable contributions to our knowledge of South Asian intellectual traditions in the early modern period (circa 1550-1750), but which neglected to include Vedānta as a point of focus. The present issue also draws inspiration from a pioneering 2011 article by Christopher Minkowski, "Advaita Vedānta in Early Modern History," which demonstrates both the possibility and the desirability of reconstructing not just an intellectual history but also a social history of Advaita Vedānta.

Michael S. Allen's article, "Greater Advaita Vedānta: The Case of Niścaldās," calls into question the standard picture of Advaita Vedānta as an essentially Sanskrit philosophical tradition. Allen argues for a much more expansive view of the tradition, which he labels "Greater Advaita Vedānta," in contrast to "Classical Advaita Vedānta" or Advaita Vedānta as expressed in the works of thinkers such as Śankara, Vācaspatimiśra, Padmapāda, Śrīharṣa, Citsukha, Madhusūdhana Sarasvatī, and so on. He believes that Advaita Vedānta's rise to prominence cannot be fully understood if we limit ourselves to this classical canon. Instead, we must attend to the wider dissemination of Vedāntic ideas through vernacular works, through narrative and dramatic works, and through works blending Vedāntic teachings with Bhakti, Yoga, and Tantra. Allen's article focuses especially on vernacular Vedānta, drawing attention to a Hindi work once referred to by Vivekānanda as the most influential book of its day: the Vicārsāgar, or "The Ocean of Inquiry," by Niścaldās (circa 1791-1863), a member of the Dādū Panth. Allen argues that the popularization of Advaita Vedānta began long before the British colonial period, and he points to a trove of vernacular Vedāntic materials still awaiting study.

Eric Steinschneider continues the theme of vernacular Vedānta in his article "Arguing the Taste of Fresh Butter: Īcūr Caccitānanta Cuvāmikaḷ's Advaitic Interpretation of Tamil Śaiva Theology." Steinschneider examines a nineteenth- 
century commentary on the Kaivalliyanavanittam, a work on Advaita Vedānta in Tamil that was widely read during the colonial period. His article examines the rhetorical and hermeneutical strategies employed by the commentator, İcūr Caccitānanta Cuvāmikal, to adapt the tradition of Advaita Vedānta to the predominant vernacular theology of Tamil Śaivism. Steinschneider argues that the way in which Advaita Vedānta and Tamil Śaivism are implicated in Caccitānanta's commentary complicates monolithic and mutually exclusive readings of both traditions, suggesting instead that engagement with the intellectual resources of nondualism in the Tamil country was a "plural, negotiated, and highly contextualized affair."

Elaine M. Fisher turns to an earlier period of theological rapprochement between South Indian Śaivism and nondualist Vedānta philosophy in her article "Remaking South Indian Śaivism: Greater Śaiva Advaita and the Legacy of the Śaktiviśiștādvaita Vīraśaiva Tradition.” Appaya Dīkșita is often credited with having single-handedly inaugurated the tradition of Saiva Advaita in the late sixteenth century, but Fisher shows that the truth is more complex and that Appaya was by no means the only South Indian thinker whose reformulation of Śaivism was influenced by nondualist Vedānta. She identifies a larger pattern that might be termed "Greater Śaiva Advaita," or the appropriation of Vedāntic language and theology across a number of distinct Śaiva lineages_-Vīraśaiva, Saiddhāntika, and Smārta-in late medieval and early modern South India. She draws attention in particular to Śaktiviśsistāâvaita, a school of Vīraśaiva theology (in Sanskrit, Kannada, and Telegu) that provides an important "missing link" between Śrīkaṇtha's thought and later forms of Śaiva Advaita, which by the seventeenth century had come to dominate South Indian Śaivism.

In his article "Parabrahman Among the Yogins," Jason Schwartz provides a provisional account of the way in which practices of yogic self-cultivation moved from the periphery to the center of Advaita Vedānta at both a scholastic and institutional level. From the thirteenth century onward, orthodox Advaitin exegetes proceeded to justify the incorporation of pan-Indic practices associated with Patañjalian and Șaḍanga Yogas as integral to the realization of Brahman. Schwartz documents how this interpretive choice made Advaita Vedānta available as a conceptual resource to a range of other renunciate traditions, blurring the lines between the practices and social identities of the Advaitin Paramahamsa and his Tāntric analogues. He concludes by demonstrating the persistence of these modalities down to the present day in the lineage of Jagadgurus at Śrngeri Matha.

In different ways, each of these articles demonstrates the need not just for further studies of Advaita Vedānta, but for new approaches to studying the tradition. Allen and Steinschneider ask us to rethink the canon of Advaita Vedānta, pointing to a vast corpus of unstudied vernacular texts. Fisher's study of Śaiva Advaita in the Tamil South invites further studies of the influence of Advaita Vedānta on local communities that might or might not have accepted Advaitin metaphysics wholesale, while Schwartz begins to map the complex relationship of Advaita Vedānta and pan-Indian traditions of Yoga and Tantra. These articles should not be read as isolated attempts to shore up gaps in our current knowledge; their intention is rather to reveal just how many gaps there are and how much work remains to be 
done-to show that Advaita Vedānta is not over-studied but under-studied. It is a question of looking beyond the standard picture, or stepping outside of existing ruts, to pursue new directions like the ones suggested here. An analogy from the Vedānta tradition itself is apt: we attempt to point out the moon, not directly, but along the dark branches of a tree, scraggly and nonlinear though they may be. What the moon itself looks like, in the end, is a matter we leave for future research.

\section{References}

Minkowski, Christopher. 2011. "Advaita Vedānta in Early Modern History." South Asian History and Culture 2, 2: 205-31.

Potter, Karl H. 2017 [1970]. Bibliography of Indian Philosophies. Available at: faculty.washington.edu/ kpotter/. 